\title{
Back to school
}

\section{The US National Science Foundation may soon have to supply lab equipment to poverty-stricken high schools. David Goldston explains why some politicians want the agency to pay for Bunsen burners and test-tubes.}

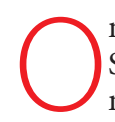
n 28 March, the House Committee on Science and Technology approved a measure that would put the National Science Foundation (NSF) in the business of equipping science laboratories in high schools that serve poor students.

Buying better high-school lab equipment is certainly a worthy goal and perhaps a legitimate use of federal money. Although education in the United States is mainly the province of state governments and local school districts, the federal government already provides billions of dollars to high schools that serve the poor via Department of Education programmes.

But paying for beakers is an unlikely task for the NSF. Supporting science and maths education at all levels is as much a part of the NSF's mission as supporting research, but its education efforts have traditionally focused on programmes to enhance teacher training, to create curricula and to promote experiments in educational approaches. The agency has not funded expensive purchases of books or equipment, largely because it tries to maximize the impact of its relatively small education budget. The NSF's annual spending on pre-college education can be counted up in different ways, but it is certainly less than $\$ 500$ million a year not much if it's to be spread around for routine purchases by every US school district.

So how did this legislation get on the agenda? The idea has been pushed over the past two or three years by the National Science Teachers Association and the American Chemical Society, which worked first with black and Hispanic members of Congress and then with members interested more generally in science education. The recent committee action was based on a bill sponsored by Representative Rubén Hinojosa (Democrat, Texas), who chairs the education task force of the Congressional Hispanic Caucus. One lobbyist told me: "The bill is a great way to get minority members interested in the National Science Foundation." And the bill moved quickly in the Democratic Congress because it was perceived as a way of showing concern for minorities.

The problem with this is not that the bill is targeted at poor and minority areas. The NSF runs several programmes to encourage minority students to study science, maths and engineering - and should probably run more, given the significance and extent of the shortfall. But

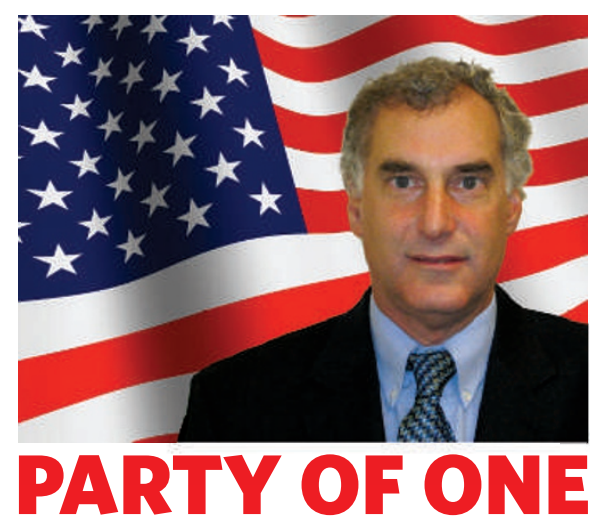

building interest in the NSF by presenting it as an agency that can dole out funding to local school districts, of any stripe, is asking for trouble.

Not only does the NSF lack the funding to take on such a role, it also lacks the staff to ensure the money would be used properly. The agency's inspector-general regularly complains that the agency's traditional grants in research and education are not followed up adequately. Saddling it with a hodge-podge of local efforts is likely to weaken the NSF's reputation for running targeted, prestigious and apolitical programmes - the very reputation that leads Congress to try to add to its responsibilities in the first place.

The school-lab bill is not the first time the NSF has been conscripted into minority politics. In 2003 and 2005, then-Senator George Allen (Republican, Virginia) offered a bill to have the NSF buy computers for colleges that were created to serve, or which now serve, predominantly minority students. Allen gave the task to the NSF because of the agency's reputation and because he served on the committee that oversees the NSF. The Senate passed the bill twice, but it always stalled in the House. (As chief of staff of the science committee, I was involved in deciding how to handle both the Hinojosa and Allen bills in past Congresses.)

When Allen's re-election effort ran into trouble last year because of charges of racism, the Republican leadership made some efforts to see whether the bill could be revived at the last minute. Nothing came of it, largely because the House Committee on Education and the Workforce remained opposed.

Proponents of the Allen bill tried to justify their efforts by citing a study, by the National Association for Equal Opportunity in Higher
Education, that they said showed the need for computer equipment at minority institutions. But the study's main point was that the institutions did not know how to make the best use of computer equipment they already had.

Similarly, advocates of the Hinojosa bill cite the National Academy of Sciences' 2005 publication America's Lab Report: Investigations in High School Science. That report does point out that non-Asian minorities generally have access to poorer labs and get less time in them, but its main conclusions do not focus on equipment. Instead it notes how limited education research, inadequate teacher training, bad curricula and misguided science standards result in labs being used in ways that are unlikely to enhance education. Equipment is the least of it.

But Congress is best at providing tangible goods, so that tends to be the focus of legislation, regardless of whether it is the greatest need.

Staff members on the science committee were sensitive to some of these issues, so the approved version of the Hinojosa bill is an improvement over the initial legislation. The programme is now authorized as a \$5-million 'pilot' rather than the \$50-million-a-year ongoing programme originally proposed. And applicants must couple the equipment purchases with teacher training. The bill requires anyone who wins federal funding to match it, and the committee may encourage, but not require, that the non-federal portion pays for the actual equipment purchases.

This approved version was put forward by Representatives Eddie Bernice Johnson (Democrat, Texas), who belongs to the Congressional Black Caucus and has long been a supporter of the NSF, and Vernon Ehlers (Republican, Michigan), a physicist with a longstanding interest in science education. They offered it as an amendment to a larger science-education bill that the House is likely to take up later this spring.

That bill, in turn, is likely to become part of a larger negotiation with the Senate over legislation meant to keep America competitive in the world economy. Congress will then have to decide whether a measure that assigns the NSF the task of buying test-tubes for the nation's most troubled high schools is the best way to have the agency contribute to US competitiveness.

David Goldston is a visiting lecturer at Princeton University's Woodrow Wilson School of Public and International Affairs. 